\title{
Impact of Micro-Credit on Livelihoods of Rural Poor in the Punjab, Pakistan
}

\author{
Muhammad Luqman1,2, Shiwei Xu1 ${ }^{*}$, Wen Yu1, Muhammad Yaseen1,2, Liwei Gao1 \\ ${ }^{1}$ Agricultural Information Institute, Chinese Academy of Agricultural Sciences, Beijing, China \\ ${ }^{2}$ Department of Agricultural Extension \& Rural Development, University College of Agriculture, University of \\ Sargodha, Pakistan \\ Email: *muhammadluqman_uos@yahoo.com
}

Received 22 May 2016; accepted 28 May 2016; published 31 May 2016

Copyright (C) 2016 by authors and Scientific Research Publishing Inc.

This work is licensed under the Creative Commons Attribution International License (CC BY).

http://creativecommons.org/licenses/by/4.0/

(c) (i) Open Access

\begin{abstract}
Rural poverty is a major socio-economic issue of many of the developing countries including Pakistan. Different strategies are being used to combat with rural poverty including disbursement of micro-credit by different state or non-state institutions in the country. In order to find out the impact of micro-credit on livelihoods of rural poor in the Punjab province of Pakistan, the present study was designed. Survey research design using mix method approach to data collection was used. Both probability (simple random) and non-probability sampling procedure was adopted for the selection of study objects. The total sample size of study was 150 (both male and female recipients of micro-credit). Descriptive (Frequency, \%, mean, SD) and inferential statistics (multiple regression) was used for the interpretation of data through SPSS. It was concluded from the results that majority of the recipients of micro-credit was belong to young age category (mean age 36 Years) with low educational status. The educational level of rural women is very low compared to men. A large majority $\mathbf{( 7 8 . 0 \% )}$ of the micro-credit recipients were female having low monthly income (119USD). Disbursement of micro-credit was one of the major strategies to cope with the issues of rural poverty. The average loan size as received by respondents was continuously increasing every year. In the research area illiteracy was on the top among other reasons of poverty with highest mean value (4.49/5.00). Majority of the respondents reported that micro-credit had significant impact in uplifting their livelihoods. It was suggested that micro-credit disbursement to the poor is not a sustainable solution to reduce poverty. The state should start other income generation activities in rural areas.
\end{abstract}

\section{Keywords}

Impact, Micro-Credit, Livelihoods, Rural Poverty, Pakistan

\footnotetext{
${ }^{*}$ Corresponding author.
}

How to cite this paper: Luqman, M., Xu, S.W., Yu, W., Yaseen, M. and Gao, L.W. (2016) Impact of Micro-Credit on Livelihoods of Rural Poor in the Punjab, Pakistan. Open Journal of Social Sciences, 4, 305-313. 


\section{Introduction}

Poverty is a sate having many dimensions which may be income based or non-income based. Different economists defined income base poverty in different ways. The comprehensive definition of poverty is that is the inability of a person to meet his/her daily requirements for health living [1]. In more simple words it is the state of deficiency in the overall comfort of an individual with minimum monitory resources [2]. Such individuals have no capacity to support themselves as well as their families for healthy living. The other dimension of poverty is non-income based. According to social scientists, non-income poverty is the lack of access to basic human, social, cultural and economic rights by an individual on individual or societal basis. In addition, poor participation by sections of society on equality basis is also termed as non-income based dimension of poverty [3]. All the individuals who are in state of income and non-income poverty are the deprived and marginalized masses of any society. Because both income and non-income nature of poverty has adverse impacts on their livelihoods [4].

Both income and non-income nature of poverty is present in every society and region since the creation of mankind and this universe in different shapes and modalities. Research studies on poverty showed that poverty is a rural phenomenon as about $75.0 \%$ of the total world's poor people are living in rural areas [5]. Economists and social scientists proved that people who used to live in rural localities are more vulnerable to poverty and food insecurity due to the one or other reason [6] [7]. Out of the total poor people of the world, it is reported that about 176 Million chronic ${ }^{1}$ poor people are residing in South Asia. Due to the poor performance of economic, social and human development indicators, such countries are referred to as fragile states. The major reason behind this high poverty rate in these countries is that, state departments are failed to deliver basic socio-economic services to all the people at their door-steps [8].

Like other countries of South Asian region, same fate of poverty also exists in Pakistan. According to Ali et al., (2010) poverty in rural areas was found to be double compared to urban areas. Keeping in view the multidimensional nature of poverty in Pakistan, the special focus and concern of economists and other development practitioners is on poverty reduction through sustainable growth in economy. Different state and non-state institutions are widely engaged in implementing poverty reduction strategies since many decades. This is very common perception around the globe that micro-credit serve as a powerful tool in poverty reduction. Specifically, in less developed countries extensive evidences are present to prove the role of micro-credit in poverty reduction [9].

With this perception, a number of social scientists and policy makers are engaging in designing strategies to smooth and efficient delivery of micro-credit to maximum number of poor people in the world. In Pakistan also, a number of state and non-state institutions and commercial banks are involved in delivery of micro-credit to the poor people in rural areas [10]. Many non-state institutions e.g. non-governmental organizations (NGOs), or non-profit organizations (NPOs) are involved in disbursement of micro-credit the poor people [11]. On international level, different researchers reported that micro-credit, if it is readily available for resource poor particularly for rural people on minimum or no interest rate will play significant role in rural poverty reduction [12]-[14] and many others). With this notion, the present study was designed to assess the impacts of micro-credit on livelihoods of rural poor with following research questions:

1. What are the description of socio-economic profile of respondents

2. In your opinion what are major causes of rural poverty and how it can be reduced?

3. What is the average size of micro-credit loan on annual basis?

4. What are the major impacts of micro-credit on the livelihoods of poor people?

\section{Theoretical Framework}

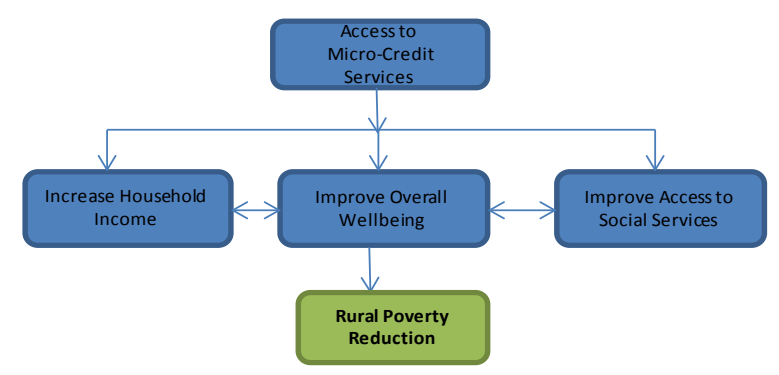

${ }^{1}$ The people who are in state of poverty since a long time are the chronically poor people. 


\section{Methodology}

The present study was conducted in the Punjab province, Pakistan which is highly populous province among other provinces. According to the estimation report by the Government of Pakistan the share of Punjab province in total population of the country is about $50 \%$. Major share of agricultural production comes from this district as agriculture is the major source of income for the livelihoods of majority of its population. The province is divided into three agro-ecological zones as Southern Zone, Central Zone and Northern Zone.

\subsection{Research Design}

Cross-sectional survey research design was used for the present research as the data were collected from respondents within a single span of time.

\subsection{Data Collection Techniques}

In this study mix method approach using both qualitative (Key-informant Interviews \& Focus Groups) and quantitative (face to face interviews) techniques was used for the collection of data. Both interview guide (for Key-informant \& Focus Groups Interviews) and interview schedule (for face-to-face interviews) were prepared keeping in view the research questions of the study for the collection of data from respondents. The content and face validity of both the research instruments were checked before data collection.

\subsection{Sampling Technique}

Keeping in view the complex nature of rural poverty, its dimensions and rural livelihood realities of the research area, sampling procedure was completed in three phases using both probability and non-probability sampling design. During 1st phase one district from each agro ecological zone was selected by using simple random sampling (probability sampling). In the 2nd phase from the selected three districts, an inventory of institutions that used to disburse micro-credit to the farmers with low interest rate and minimum legal formalities was prepared with the help of key informants and all the stakeholders. From that inventory one institution from which majority of the rural people used to get micro-credit was purposefully selected (non-probability sampling). The purpose of the selection was the popularity and credibility of institution in disbursing micro-credit to the rural people who are resource poor with no other financial liability on the part of people who used to get credit. In the 3rd phase list of recipients of micro-credit from the concerned institution was taken from each list of three selected districts, 50 recipients were randomly selected and face-to-face interviews were conducted with the selected respondents.

\subsection{Data Analysis}

The collected data were analyzed with the help of SPSS. Both descriptive and inferential statistics was used for the interpretation of data. Multiple regression model was used to find relationship between dependent and independent variables. In the present research, Improvement in Livelihoods (IL) was selected as dependent variable while on the other hand Access to Micro-Credit Services (AMCS) and Simplicity of the Micro-Credit Disbursement Procedure (SMCDBP) were used as independent variables. In the form of equation, these variables are given and explained below:

$$
\begin{aligned}
& \mathrm{Y}=\mathrm{B}_{0}+\mathrm{B}_{1} \mathrm{X}_{1}+\mathrm{B}_{2} \mathrm{X}_{2}+\mathrm{e} \\
& \mathrm{IL}=\mathrm{B}_{0}+\mathrm{AMCS}_{1}+\mathrm{B}_{2} \mathrm{SMCDBP}_{2}+\mathrm{e} \\
& \mathrm{IL}=\mathrm{Improvement} \text { in Livelihoods } \\
& \text { AMCS = Access to Micro-Credit Services } \\
& \text { SMCDBP = Simplicity of the Micro-Credit Disbursement Procedure }
\end{aligned}
$$

\section{Results and Discussion}

\subsection{Socio-Economic Profile}

(Age) The data regarding age of the respondents as given in Table 1 showed that average age was found to be 36 years, which shows that majority of the respondents who used to get micro-credit were mostly belong to 
Table 1. Age of the respondents.

\begin{tabular}{ccc}
\hline Minimum Age & Maximum Age & Average Age \\
\hline 18 Years & 66 Years & 36 Years \\
\hline
\end{tabular}

(Source: Survey Data by Author).

young age group. This showed that young people are more inclined towards lending of micro-credit. During Focus Group Discussion meetings, the question was raised to find out the age group who mostly involve in lending micro-credit? Majority of people responded that due to minimum availability of other income generation activities as well as employment opportunities for generation in the country, young people used to start small business or micro-enterprises to earn income for their livelihoods. Similar results were also reported by [15]. They studied the impact of micro-finance on poverty reduction in the Punjab, Pakistan.

The data regarding age of the respondents as given in Table 1 showed that average age was found to be 36 years, which shows that majority of the respondents who used to get micro-credit were mostly belong to young age group. This showed that young people are more inclined towards lending of micro-credit. During Focus Group Discussion meetings, the question was raised to find out the age group who mostly involve in lending micro-credit? Majority of people responded that due to minimum availability of other income generation activities as well as employment opportunities for generation in the country, young people used to start small business or micro-enterprises to earn income for their livelihoods. Similar results were also reported by [15]. They studied the impact of micro-finance on poverty reduction in southern region of the Punjab, Pakistan.

(Gender) The data regarding gender is presented in Table 2 given below:

The data regarding profile of respondents on the basis of gender showed that a large majority (78.0\%) of the respondents were female who used to get micro-credit facilities to improve their livelihood status. This showed that rural women were more inclined to get micro-credit as compared to men. The reason might be due to the limited availability of income generation activities for women in rural areas as compared to men. During focus group discussion, it was noted that the major purpose of lending micro-credit for majority of the rural women was purchase of livestock and poultry. They used income that they earned from that livestock and poultry on different household expenses. The findings of the present research are confirmed the results explained by [15]. The other reason of women's more involvement/interest in getting is the high poverty rate among rural women. Women in rural areas of Pakistan are more vulnerable to poverty as compared to men [16]. Due to the presence of high poverty rate and under nourishment among rural women in Pakistan, micro-finance/micro-credit institutions are paying more attention and emphasis on disbursing micro-credit to women.

(Income) Income is very much important for the livelihoods of individuals. The data regarding monthly income of respondents is given as in Table 3.

The data presented above shows the poverty status of people in the research area. This is very much clear from the data that majority of the people are facing the problem of poverty as they have very low income. Even in some cases, households didn't have enough money for the medical treatment of themselves and their families and also for the education of their children. Due to that reason majority of the poor people in rural areas are facing the problems of food insecurity and undernourishment especially female.

(Education) Education is one the important human capital. It plays a key role in poverty reduction and for better earnings for livelihoods. The data regarding education of the respondents is tabulated in Table 4.

The data presented in Table 2 majority (39.3\%) of the respondents were illiterate followed by 34.0\% who have only five years of schooling. This showed the low educational level in rural areas. Out of the study respondents, no person had education upto graduation (higher education particularly in Universities/degree awarding institutes). These results confirmed the statistical data regarding literacy ratio at national level in Pakistan. According to the report of Government of Pakistan literacy rate in rural areas was low as compared to urban areas [17]. Very interesting and unfortunate results was found regarding educational level of women in the research area as majority of the respondents was female as presented in Table $\mathbf{5}$.

The results showed that illiteracy among rural women is very common in the research area just like other parts of the country. These results proved the low literacy ratio of rural women in Pakistan as stated by [17].

\subsection{Reasons of Poverty}

Since many decades Pakistan is facing a number of social and economic issues. Out of these issues, poverty 
Table 2. Gender profile of respondents.

\begin{tabular}{ccc}
\hline Gender & Frequency & Percentage \\
\hline Male & 33 & 22.0 \\
Female & 117 & 78.0 \\
Total & $\mathbf{1 5 0}$ & $\mathbf{1 0 0 . 0}$ \\
\hline
\end{tabular}

(Source: Survey Data by Author).

Table 3. Monthly income of respondents.

\begin{tabular}{ccc}
\hline Minimum Monthly Income & Maximum Monthly Income & Average Monthly Income \\
\hline 3000 PKR (30USD) & 85000 PKR (850USD) & 11919 PKR (119USD) \\
\hline
\end{tabular}

(Source: Survey Data by Author).

Table 4. Educational profile of respondents.

\begin{tabular}{ccc}
\hline Education & Frequency & Percentage \\
\hline Illiterate & 59 & 39.3 \\
Primary (five years of schooling) & 51 & 34.0 \\
Matric (10 years of schooling) & 13 & 8.7 \\
Intermediate (12 years of schooling) & 27 & 18.0 \\
Total & $\mathbf{1 5 0}$ & $\mathbf{1 0 0 . 0}$ \\
\hline
\end{tabular}

(Source: Survey Data by Author).

Table 5. Male and female Literacy ratio of respondnets.

\begin{tabular}{cccc}
\hline Education & Gender & & Total \\
\hline Illiterate & Male & Female & 27 \\
Primary (five years of schooling) & 5 & 54 & 59 \\
Matric (10 years of schooling) & 8 & 43 & 13 \\
Intermediate (12 years of schooling) & 4 & 9 & 51 \\
Total & 16 & 11 & $\mathbf{1 5 0 . 0}$ \\
\hline
\end{tabular}

(Source: Survey Data by Author).

which is very much common in rural settings is the major one. In the present, the respondents were asked to tell about the major reasons of widespread rural poverty and their responses were recorded on five point likert scale. The descriptive (mean and SD) of the said data is presented in Table 6.

The data presented in Table 4 showed that among other reasons of rural poverty in the research area, lack of access to educational facilities or other words illiteracy was on the top with highest mean vale (4.49/5.00). This clearly indicate that majority of the respondents were fully agreed that illiteracy or low educational level in rural areas is the main cause of rural poverty. And this has been already discussed that illiteracy is very common in the research area as majority of the respondents were illiterate (see findings of Table 2 regarding education). All other reasons of poverty as pointed out by the respondents had mean greater than 3.5/5.00 which showed that majority of the respondents were agreed regarding reported reasons of poverty. These findings confirmed the results reported by references [18], [19] and [20]. 
Table 6. Mean and SD of reasons of rural poverty.

\begin{tabular}{lcc}
\hline Reasons of rural poverty & Mean & SD \\
\hline Lack of access to educational opportunities/llliteracy & 4.49 & 0.602 \\
Lack of employment opportunities & 4.35 & 0.853 \\
Lack of good governance policies by the state & 4.32 & 0.756 \\
Small Land holdings and Low agricultural produce & 4.11 & 0.693 \\
Lack of access to health Facilities & 4.06 & 0.688 \\
Poor marketing facilities of agriculture produce & 4.02 & 0.723 \\
Limited access to social safety nets (SSNs) and Micro-credit facilities & 3.97 & 0.749 \\
Poor Agric. Technology transfer system & 3.82 & 0.964 \\
\hline
\end{tabular}

(Source: Survey Data by Author); (Scale: 1 = Strongly Disagree, 2 = Disagree, 3 = Undecided, 4 = Agree, 5 = Strongly Agree).

\subsection{Loan Size}

The respondents were asked question about the size of loan since last five years starting from 2010 to 2015 and the data in this regard is tabulated in Table 7.

The data given in Table 5 indicate that the amount of loan as micro-credit is increasing every year. This showed that micro-credit had significantly play role in improving the livelihoods of rural people. But the other side of the picture is that disbursement of micro-credit is not a sustainable strategy in upgrading the livelihoods. Its basic function is to give preliminary foundation to the poor people to start his/her business or any activity/ enterprise for better earning. The year wise increase in size of loan by the respondents is well explained in Figure 1 given.

\subsection{Perceived Impact of Micro-Credit on Rural Livelihoods}

The perceived impact of micro-credit on livelihoods of rural poor in the research area was determined by using 5-point likert type scale against different indicators of livelihoods. The results in this regard are given in Table 8.

The data presented in Table 6 showed that all the livelihood indicators had mean more than 3.00 which showed that majority of the respondents agreed on the opinion that microcredit had positive impacts on their livelihoods. The indicator of livelihood having maximum mean value $(\bar{x}) 4.27 / 5.00$ was that micro-credit decrease the vulnerability of people to poverty and other environmental shocks. The results also showed that micro-credit also had positive role in poverty reduction having mean value 4.05/5.00. These results confirmed the findings reported by [21] who concluded that micro-credit is an effective tool against poverty reduction. The same was also reported by [22]. He stated that although microcredit has significant role in poverty reduction but it also has some shortcomings like small loan size, majority of people spend loan money to meet household expenses instead of starting business (this practice is very common in rural areas), lack of proper awareness among community members about micro-credit, and minimum support from the state institutions.

\subsection{Results of Regression Analysis}

Multiple regression was run on SPSS with one dependent and two independent variables and the results in this regard are given in Table 9.

The results of the regression analysis showed that Adjusted R Square is 0.650 which indicate that Dependent Variable-Improvement in Livelihoods (IL) can be easily anticipated through predictors (dependent variables) which were Access to Micro-Credit Services (AMCS) Simplicity of and Micro-Credit Disbursement Procedure (SMCDBP). Moreover, the value of $\mathrm{R}$ as correlation coefficient 0.809 indicates that dependent variable had highly positive correlation with all independent variables. Analysis Of Variance (ANOVA) table showed that value is highly significant (0.000) indicating that all the independent variables i.e. AMCS and SMCDBP are significantly forecasting the impact of Improvement in Livelihoods (IL). 
Table 7. Loan size of respondents.

\begin{tabular}{ccccc}
\hline & Year & Minimum (in PKR) & Maximum (in PKR) & Average (in PKR) \\
\cline { 2 - 4 } & 2010 & 10000 & 150000 & 19979 \\
& 2011 & 15000 & 30000 & 22900 \\
& 2012 & 15000 & 35000 & 27500 \\
& 2013 & 20000 & 350000 & 38900 \\
& 2015 & 20000 & 350000 & 49583 \\
\hline
\end{tabular}

(Source: Survey Data by Author).

Table 8. Mean and SD of different livelihood indicators regarding impcat of micro-credit.

\begin{tabular}{lcc}
\hline Indicators & Mean & SD \\
\hline Decrease vulnerability to poverty and environmental shocks & 4.27 & 0.702 \\
Contribution in family income & 4.25 & 0.725 \\
Improvement in Business & 4.17 & 0.474 \\
Improve access to educational facilities & 4.12 & 0.827 \\
Improved Overall household wellbeing & 4.09 & 0.717 \\
Increase income level & 4.07 & 0.928 \\
Reduction in poverty status & 4.05 & 0.622 \\
Improve children well-being & 3.87 & 0.730 \\
Improve household food security status & 3.78 & 0.578 \\
Improve access to health facilities & 3.65 & 0.905 \\
Improve self-respect & 3.56 & 0.755 \\
Improve decision making power & 3.53 & 0.730 \\
Improve self-confidence & 3.51 & 0.833 \\
Enhance productivity level and skills & 3.37 & 0.856 \\
Increase control over resources & 3.25 & 0.897 \\
Increase in Agricultural Land & 2.95 & 0.933 \\
\hline
\end{tabular}

(Source: Survey Data); (Scale: 1 = S. Disagree, 2 = Disagree, 3 = Undecided, 4 = Agree, 5 = S. Agree).

Table 9. Summary of regression analysis.

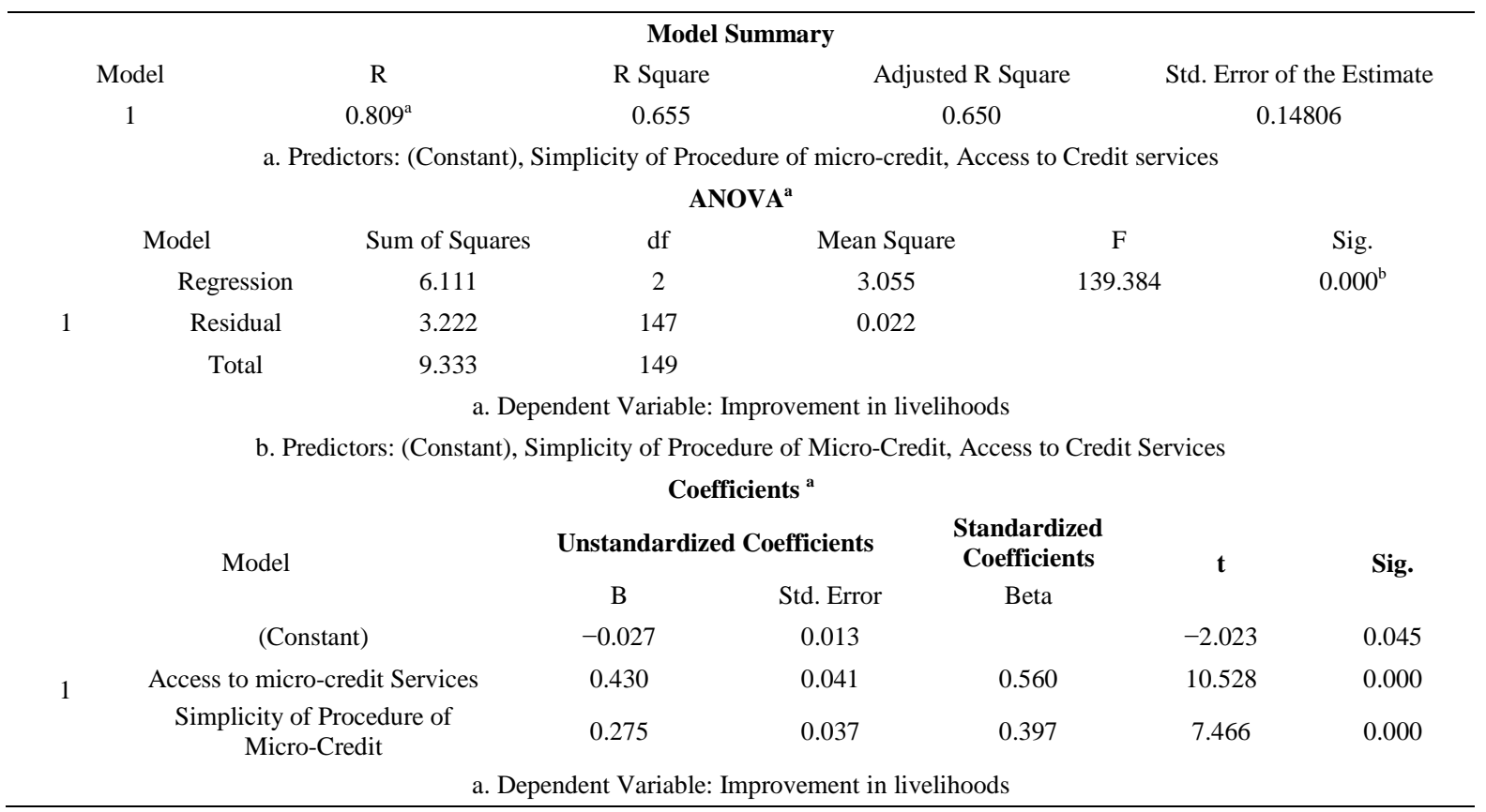




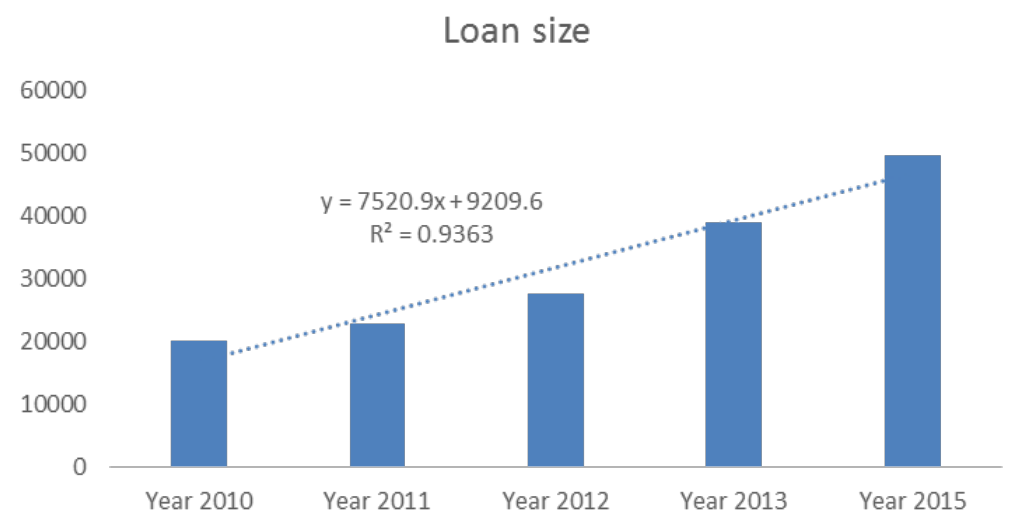

Figure 1. Loan size during the last five years.

\section{Conclusions \& Recommendations}

It was concluded from the results that majority of the recipients of micro-credit was belong to young age category (mean age 36 Years) with low educational status. The educational level of rural women is very low compared to men. A large majority (78.0\%) of the micro-credit recipients were female having low monthly income (119USD). Disbursement of micro-credit was one of the major strategies to cope with the issues of rural poverty. The average loan size as received by respondents was continuously increasing every year. In the research area illiteracy was on the top among other reasons of poverty with highest mean value (4.49/5.00). Majority of the respondents reported that micro-credit had significant impact in uplifting their livelihoods. It was suggested that micro-credit disbursement to the poor is not a sustainable solution to reduce poverty. The state should start other income generation activities in rural areas.

\section{Acknowledgements}

This study was supported by the program CAAS-ASTIP-2016-AII. The authors thanks for support from innovation fund founded by the Chinese Academy of Agricultural Sciences.

\section{References}

[1] Janjua, P.Z. and Kamal, U.A. (2011) The Role of Education and Income in Poverty Alleviation: A Cross-Country Analysis. The Lahore Journal of Economics, 16, 143-172.

[2] Ali, I., Saboor, A., Ahmad, S. and Mustafa (2010) Relative Poverty Dynamics in Pakistan. Pakistan Journal of Agricultural Sciences, 47, 45-52.

[3] Bhutto, A.W. and Bazmi, A.A. (2007) Sustainable Agriculture and Eradication of Rural Poverty in Pakistan. Natural Resources Forum, 31, 253-262. http://dx.doi.org/10.1111/j.1477-8947.2007.00162.x

[4] Ashfaq, M., Griffith, G. and Hussain, I. (2009) Economics of Water Resources in Pakistan: Water and Poverty. Pak. TM Printers, Pakistan.

[5] IFAD (2011) Enabling Poor ruRal People to Overcome Poverty in Pakistan: Rural Poverty in Pakistan. International Fund for Agricultural Development (IFAD), Rome, Italy.

[6] Adeniji, O.B. (2010) Potentials of Information and Communication Technologies for Poverty Alleviation and Food Security. Journal of Agricultural Extension, 14, 130-138.

[7] Godfray, H.C.J., Beddington, J.R., Crute, I.R., Haddad, L., Lawrence, D., Muir, J.F., Pretty, J., Robinson, S., Thomas, S.M. and Toulmin, C. (2010) Food Security: The Challenge of Feeding 9 Billion People. Science, 327, 812-818. http://dx.doi.org/10.1126/science.1185383

[8] Maiangwa, M.G., Omolehin, R.A., Adeniji, O.B. and Mohammed, U.S. (2010) Food insecurity: Challenges of Agricultural Extension in Developing Countries. Journal of Agricultural Extension, 14, 73-105.

[9] Chaudhry, I.S., Faridi, M.Z. and Hanif, I. (2012) The Whimsical Trends of Rural Poverty in Pakistan: Some Diversifications. International Research Journal of Finance and Economics, Issue 83, 78-89.

[10] Durrani, M.K.K. (2011) Role of Micro Finance in Reducing Poverty: A Look at Social and Economic Factors. International Journal of Business and Social Science, 2, 137-144. 
[11] Mawa, B. (2008) Impact of Micro-finance Towards Achieving Poverty Alleviation. Pakistan Journal of Social Sciences, 5, 876-882.

[12] Gurses, D. (2009) Micro-Finance and Poverty Reduction in Turkey Perspectives on Global Development and Technology, 90-110.

[13] Brownstein, L., Fleck, P., Shetty, R., Sorensen, J. and Vadgama, V. (2007) Pathways out of Poverty, Microfinance to Empower Sub-Saharan Africa. Discussion Paper Series University of Minnesota, 1-57.

[14] Bakhtiari, S. (2006) Micro-finance and Poverty Reduction (Some International Evidence). International Business \& Economics Research Journal, 1-7.

[15] Fareed, Z., Shahzad, F., Arshad, M., Lodhi, R.N. and Amen, U.E. (2014) The Impact of Microfinance on Poverty Reduction (A Case Study of Okara, Southern Punjab, Pakistan). European Academic Research, 1, 3196-3217.

[16] Asian Development Bank (2002) Poverty in Pakistan: Issues, Causes and Institutional Responses. Asian Development Bank, Islamabad. Pakistan.

[17] Government of Pakistan (2015) Economy Survey of Pakistan. Economic Advisor's Wing, Islamabad, Pakistan.

[18] Chaudhry, I.S., Malik, S. and Ashraf, M. (2006) Rural Poverty in Pakistan: Some Related Concepts, Issues and Empirical Analysis. Pakistan Economic and Social Review, 44, 259-276.

[19] Khan, A.A. (2002) Agricultural Knowledge and Information System for Rural Development in Pakistan: A Case Study. FAO, Rome.

[20] Haque, U.I. (2002) Uplift of Landless Poor through Agricultural Reforms: WB. Dawn Economic and Business Review, 29 April-5 May 2002, 1-6.

[21] Akhtar, D.W., Akhtar, D.N. and Jaffri, S.K.A. (2009) Islamic Micro-Finance and Poverty Alleviation: A Case of Pakistan. Paper Presented at Second Proceedings CBRC Lahore, Pakistan, 1-8.

[22] Ahmad, S.N. (2008) Micro-Finance in Pakistan (Policies and Practice). Department of Finance and Accounting School of Management and Governance University of Twente, 1-106. 